\title{
Satan tager ordet
}

\section{Litteratur, genre og historie, belyst gennem Torquato Tassos Gerusalemme Liberata}

\author{
"[Tasso] undertrykte de vandrende riddere og ud- \\ vandt ikke sin handlingsgang fra lysten til eventyr, \\ men fra Himmelens og Helvedes gerninger, som hos \\ Homer.» \\ Francesco De Sanctis: Storia della letteratura italiana. ${ }^{1}$
}

Hvis man i dag, i Danmark, overhovedet kender til den italienske forfatter Torquato Tasso (1544-1595), så er det efter al sandsynlighed gennem eftertidens og især romantikkens litterære fantasier. De fleste har hørt om Goethes tragedie Torquato Tasso og måske også om Byrons digt Lament of Tasso, færre kender Tassos eget hovedværk, eposet Gerusalemme Liberata (Jerusalem befriet, 1581 - herefter blot Liberata), som da heller aldrig er blevet oversat til dansk. ${ }^{2}$ Det er ærgerligt, for Tasso er en af de store skikkelser ikke kun i den italienske, men også i den europæiske litteratur. Og det er ærgerligt, fordi Liberata er et vigtigt og komplekst knudepunkt i den europæiske litteraturs historie. Værket er et af de få kunstnerisk vellykkede resultater af senrenæssancens mange forsøg på at genoptage det klassiske, antikke epos, hvorfor det forudaner 1600-tallets franske klassik og dennes fetichering af de antikke genrer; i stil og tonefald peger det imidlertid fremad mod andre kunstneriske bevægelser: barokken og romantikken.

Denne artikel analyserer en enkelt scene i Liberata, 18 strofer, der fremstiller Satan og hans djævle. Ikke desto mindre er både værkets forhold til det klassiske epos og dets mange litterære nybrud centrale omdrejningspunkter. Samtidig knytter analysen an til to mere overordnede, teoretiske diskussioner. Dels viser det sig nemlig, at Liberata sætter spørgsmålstegn ved de måder, man fra den tyske idealisme og - med visse undtagelser - frem til i dag har forstået og gjort brug af de litterære genrebegreber. Og dels viser det sig, at man kun dårligt kan læse Liberatas litterære nybrud som en parallel til forandringerne i senrenæssancens kulturelle og politiske horisont. Værkets mange fornyelser viser i en vis forstand, at litteratur og historie ikke restløst går 
op i hinanden. Artiklens afslutning argumenterer for, at der er en tæt sammenhæng mellem de to diskussioner.

\section{Satan tager ordet}

Gerusalemme Liberata fortæller i tyve sange historien om middelalderens første kristne korstog, og det vil sige historien om korsriddernes belejring og erobring af det hellige Jerusalem. De faktiske, historiske begivenheder overlejres imidlertid af tildigtede scener og begivenheder - og af en religiøs ramme, der overskrider i al fald vor tids forståelse af fortiden. Bagved og gennem den jordiske krig udkæmpes i Liberata nemlig en kosmisk kamp mellem Gud og Satan, mellem himmelens og helvedes kræfter. I første sang vælger Gud således fyrsten Gotfred af Bouillon til at lede den kristne hær; herefter følger belejringen, og det vil sige hærslag, intriger og højstemte begravelser, krydret med de enkelte korsridderes ulykkelige kærlighed og flyvske eventyr i nærheden af og langt fra den kristne lejr. Djævelske magter hjælper maurerne og forsøger at stikke en kæp i hjulet på Guds planer. En overraskende stor del af den episke handlingsgang fødes ud af djævlenes forsøg på at forhindre korsriddernes endelige sejr; direkte eller indirekte forårsager de endog en række af de kristne ridderes død - ikke desto mindre kan korsridderne til slut knæle i bøn inden for murene af det befriede Jerusalem.

Kristendommens religiøse magter fylder altså godt op i Liberata. Den eneste gang, Satan selv optræder er imidlertid i begyndelsen af fjerde sang. Efter at have set korsriddernes succes i det første slag foran Jerusalems mure og set deres mange krigsmaskiner, kalder Satan sine djævle sammen. Alle passagens 18 strofer er oversat som appendiks til artiklen - her følger et citatspækket referat. ${ }^{3}$

„Derefter, da han har hele sin tankes kraft vendt mod at påføre de kristne størst mulig smerte, befaler han sit folk (forfærdende menighed!) at samles i det underjordiske rige; som om det var et let foretagende, ak hovmod!, at modsætte sig den guddommelige vilje: hovmodig er den, der gør sig til Himlens lige, og bevidst glemmer, hvordan Guds højre hånd tordner i vrede. $\|^{4}$

Så kommer en beskrivelse af de mange dæmoner, og af Satan selv:

»Pluto sidder i midten og holder i højre hånd det tunge og grove scepter; hverken skærene i havet, bjergklipperne, eller endog Gibraltars 
klipper hæver sig så højt, ej heller den store Atlantkæde, som foran ham ville synes som små bakker, så højt hæver sig panden og de store horn.

Det vilde udseendes grufulde værdighed øger rædslen, og gør ham mere hovmodig: øjnene gløder rødt, og betændt af gift glimter blikket som en ulyksalig komet. Det store skæg dækker hans hage og falder stridt og krøllet ned ad det behårede bryst, og som en dyb afgrund åbner munden sig, uren af mørkt blod. $\aleph^{5}$

Derefter holder Satan en tale for de forsamlede djævle. Først henvender han sig til sine undersåtter - de faldne engle, hans allierede i oprøret mod Gud. Han finder dem stadig værdige til at sidde i Paradis, men himlens nuværende magthaver har dømt dem oprørske:

»I Helvedes numier, mere værdige til at sidde over solen, hvor jeres oprindelse er, og som det store styrt engang sammen med mig skubbede fra de lykkelige riger ned i dette forfærdelige indelukke. Vores store forehavende, andres gamle mistanker og voldsomme harme er alt for kendte: nu hersker Han som Han vil over stjernerne, og vi anses for at være oprørske sjæle. $\aleph^{6}$

I sin tale beskriver Satan de fortidige uretfærdigheder, himlen har udsat dem for: først og fremmest Guds beslutning om at lade menneskene komme i himlen (»det usle menneske, født af ussel mudder på jorden«"), men også Kristi korsfæstelse - der besegler den nye pagt mellem Gud og menneskene, og er forudsætningen for den kristne kirke - samt Kristi befrielse af de fordømte sjæle i Helvede. I lyset af de fortidige overgreb står korstoget som endnu et angreb på Satans legitime rettigheder. Og det kan ikke gå upåagtet hen, for griber djævlene ikke ind, risikerer de og Satan at hele verden til slut tilbeder den kristne gud. Så ender helvede tømt for sjæle, og Satan bliver hersker over et tomt rige. Det er derfor både på sin plads og nødvendigt for helvedes magter at kæmpe mod korsridderne - skønt det forrige slag med Gud blev tabt, har djævlene stadig det fornødne mod til at gøre oprør mod ham.

„Endnu er dén ånd ikke død i jer, som I viste dengang, da vi omringet af jern og høje flammer kæmpede mod det himmelske herredømme. Vi blev, jeg nægter det ikke, overvundet i det slag, og dog manglede der ikke mod i den store tanke. Hvad det end var, der gav Ham sejren: længslen efter ære forblev ubesejret i os. $\|^{8}$ 
Til slut beordrer Satan djævlene ud i verden, hvor de med magt og bedrag skal bekæmpe den kristne sag.

Såvel passagens indledende beskrivelse af Satan som dennes opflammende tale er bemærkelsesværdige, og det af flere forskellige grunde. Indledningsvis er det mærkværdigt, at Satan fremstilles med en iboende værdighed - og det skønt de djævelske magters forsøg på at bekæmpe Guds vilje i en for Liberatas fortæller usædvanligt direkte kommentar bedømmes som tåbelig, og skønt det ligger i kortene, at også dette nye oprør mod Gud er dømt til at mislykkes. Denne værdighed gør ham endog endnu mere frygtindgydende - »det vilde udseendes grufulde værdighed øger rædslen«, som der står. Selv om djævelen til syvende og sidst er magtesløs, så er han i Liberata både storslået og rædselsvækkende.

Mange andre passager i Liberata udtrykker en traditionel kristen teologi. På trods af fortællerrøstens indbrud giver ovenstående passage, og især Satans tale, et kort øjeblik plads til en temmelig utraditionelt gestaltning af Satan. Følger man denne gestaltnings indre logik (idet man ser bort fra fortællerrøsten) er der faktisk ingen principiel forskel mellem Gud og Satan. Begge har jordiske tilbedere, begge har en hær af engle til deres disposition og begge holder et vågent øje med begivenhederne på jorden. ${ }^{9}$ Denne 'utraditionelle' gestaltning styrkes af Satans egen tale, som nok udlægger kristendommens historie, men gør det set ud fra Satans perspektiv. Selve talens eksistens forlener skikkelsen med en vis grad af selvstændig refleksion - lader ham fortolke sin egen position i forhold til Gud og verden. Og selv om talens indhold ud fra et traditionelt, kristent perspektiv udtrykker netop det hovmod, der førte til Satans fald, så giver den ham ikke desto mindre mulighed for at udtrykke sit eget syn på verden. For et kort øjeblik tager Satan ordet, og det ikke blot fordi han taler, men fordi hans synspunkt kommer til udtryk - et synspunkt, der nok modsiges af fortællerrøsten, men ikke af den måde, Satan-skikkelsen i øvrigt gestaltes. ${ }^{10}$

I sin gestaltning accentuerer passagen det, man kan kalde Satan-som-Lucifer, den faldne engel. Hos Tasso er Satan først og fremmest dén, der gør oprør mod Gud. Først derefter er han dén, der frister mennesket. Også det er bemærkelsesværdigt, især set i lyset af den værdige og højstemte tale til forsamlingen af djævle. Faktisk udgør skikkelsen en markant fornyelse i Satanskikkelsens litterære historie. Ganske vist er den talende djævel en kendt figur i kristen mytologi, hvis rødder går tilbage til slangen i paradis, Jobs bog og det nye testamentes fortællinger om de tredive dage i ørkenen. Men disse (og mange af litteraturens senere) Satan-skikkelser er alle eksempler på det, man kan kalde Satan-som-Mefistofeles. Her gestaltes Satan som en frister af mennesket, ikke som en oprører mod Gud; hans narrative repertoire og hele 
tonefald er derfor et andet end det, vi forbinder med Satan-som-Lucifer. Og selv om en talende Lucifer kan findes i enkelte kristne mysteriespil, så er han dér en grovkomisk narrefigur, ikke en højstemt oprører. ${ }^{11}$ Ydermere: hvor disse genfortalte apokryfe og bibelske historier (Lucifers oprør, syndefaldet, Kristi lidelseshistorie, Kristus slår portene til helvede ind) ikke indsatte Lucifer i samtidens og fortidens 'prosaiske' historie, så agerer Tassos Satan-somLucifer i den faktiske, historiske fortid, nemlig det første korstogs forsøg på at erobre Jerusalem.

Det fornyende i Liberatas gestaltning af Satan ses også, når man sammenligner den med fremstillingen af Lucifer og Pluto i Dantes La Divina Commedia. Også hos Dante er Lucifer (som den faldne engel) gigantisk, men han er frosset fast til Helvedes bund, hvor han med sine munde tygger på Judas, Cassius og Brutus; Pluto (Tasso kalder Satan for »Pluto«) er reduceret til en fordømt sjæl i helvede, der ganske vist siger de truende, uforståelige ord »Papé Satan, Papé Satan aleppe« - men hurtigt skræmmes til ro af Vergil. ${ }^{12}$ Hos Dante er de dæmoniske kræfter således fuldt og helt indlejret i Guds kosmologi. De har intet råderum, men må magtesløst udføre de opgaver, de er tildelt i den kristne verdensorden - deres eneste forsøg på selv at komme til orde er meget sigende ikke til at forstå. Tassos Satan har derimod sit eget syn på verden og får mulighed for at udtrykke det. Samtidig har han en vis narrativ frihed - han lægger endog betydelige hindringer i vejen for korsriddernes erobring af Jerusalem.

Med alt dette in mente bliver fornyelserne i Tassos Satan-skikkelse for alvor synlige. Så vidt jeg kan se, er Tasso den første forfatter i den europæiske litteraturs historie, som fremstiller Satan som en reflekteret, talende og storslået oprører mod Gud, og det vil sige: fremstiller Satan som en falden engel, der til stadighed og aktivt gør oprør. Men Tassos Satan er ikke kun bemærkelsesværdig, fordi han er gestaltet, som han er. Selve det, at han optræder som gestaltet figur i et højlitterært italiensk værk fra 1500-tallet, er usædvanligt. I den tidligere renæssances litterære tradition optræder nemlig masser af dæmoner og troldmænd, men man finder ikke Gud og Satan som konkrete narrative figurer. Og i andre af renæssancens forsøg på at genoptage den klassiske epik optræder Gud ganske vist, men Satan er fraværende. ${ }^{13}$ Spørgsmålet er derfor ikke blot, hvorfor Satan er gestaltet, som han er, men også hvorfor han overhovedet optræder i et litterært værk fra senrenæssancen. 


\section{Modreformation og angsten for tyrkerne}

I en vis forstand knytter Satans tilstedeværelse i Liberata an til spørgsmålet om, hvorfor Tasso overhovedet skrev et epos om middelalderens første korstog, et emne der i eminent grad lader sig overlejre af kampen mellem Gud og Satan. Og det hænger - i al fald på et overordnet niveau - igen sammen med senrenæssancens kulturelle og politiske horisont, mere præcist tidens utopiske forhåbninger om et »nyt korstog«, en generobring af Jerusalem fra muslimerne. Disse havde fået ny aktualitet i årene omkring Liberatas tilblivelse, ikke blot fordi det osmanniske riges ekspansion op gennem 1500tallet var en stadig mere aktuel trussel mod den italienske østkyst, men også fordi en alliance af kristne fyrster i slaget ved Lepanto i 1571 for første gang vandt en betydningsfuld sejr over de fremrykkende tyrkere. I senrenæssancen var kampen mod et muslimsk folk ikke blot fortidig historie, men i høj grad aktuel nutid, og efter 1571 voksede den (illusoriske) drøm om, at de kristne magter kunne komme i offensiven. Liberatas genfortælling af middelalderens første korstog er således også en opfordring til et nyt, hvilket værkets første strofer gør klart. Her opfordrer Tasso de kristne fyrster til - som i middelalderen - at glemme deres interne stridigheder og samles under den katolske kirkes banner. ${ }^{14}$

Nu tog ikke blot Tasso, men også en række af den tidligere italienske renæssances ridderdigte ${ }^{15}$ deres udgangspunkt i den tidlige middelalders kampe mellem muslimer og kristne. Men skønt det centrale slag i Ludovico Ariostos Orlando Furioso (1532) nok står mellem maurere og kristne, så udgør de religiøse kampe her blot et bagtæppe for de forskellige - muslimske og kristne - ridderes løsrevne, fantastiske eventyr. Således ikke i Liberata. Her er korstoget udtryk for den evige kamp mellem himmel og helvede; her underordnes de enkelte ridderes eventyr både narrativt og tematisk erobringen af den hellige stad. Af samme grund fylder de djævelske magter så meget hos Tasso. Underordner man alle begivenheder kampen mellem himmel og helvede, ja, så ender enhver forhindring på vejen mod Jerusalems erobring også med at være djævelens værk.

Der kan ikke gives én bagvedliggende grund til Liberatas eksplicitte religiøsitet; angsten for de fremrykkende osmannere spiller også ind her, det samme gør eposets historiske ramme, belejringen af Jerusalem. Men først og fremmest må man pege på påvirkningen fra senrenæssancens religiøse klima. Efter en noget forvirret reaktion på protestantismens fremmarch lancerede den katolske kirke fra og med Trentinerkonciliets afslutning i 1563 en kras religiøs modoffensiv, der ikke blot rettede sig mod de protestantistiske lande, men også - med indførelsen af en effektiv censur og et vidtforgrenet netværk 
af inkvisitionsdomstole - stilede mod at overvåge og kontrollere det intellektuelle klima i det katolske Europa. Modreformationens kristne hegemoni prægede således Tassos samtid, og efter alt at dømme også forfatterens sind. I al fald meldte Tasso flere gange sig selv til inkvisitionen som kætter, ligesom han frivilligt underlagde Liberata en religiøs forcensur for at sikre sig, at værket ikke indeholdt anstødeligt materiale.

For så vidt som de djævelske magters tilstedeværelse i Liberata opstår i en vekselvirkning mellem det valgte emne - korstoget - og den religiøse accentuering af samme emne, så finder man altså baggrunden for Satans tilstedeværelse i samtidens politiske og kulturelle horisont. Denne historiske kontekst giver imidlertid ikke svar på, hvorfor de djævelske magter i Liberata figureres på netop den måde, de gør. Af samme grund giver den ingen forklaring på, hvor baggrunden for de distinkt nye elementer i Tassos gestaltning af Satan skal findes. Her må man i stedet se på Liberatas forhold til den episke genre - og det vil sige på samspillet med de klassiske eper, på senrenæssancens genreteoretiske refleksioner og på den eksisterende litterære tradition i renæssancens Italien. Inden det kan blive belyst, er det imidlertid nødvendigt med en receptionshistorisk og genreteoretisk ekskurs.

\section{Genren og historien}

Kort efter Liberatas udgivelse blev værket centrum for en af renæssancens bitreste litterære diskussioner. Centralt i denne stod spørgsmålet om, hvorvidt værket var et rigtigt epos eller ej - et spørgsmål, der også har optaget store dele af den senere kritikhistorie. Den romantisk prægede reception af Liberata anerkendte således nok værkets episke status, men fokuserede samtidig på det, man kaldte dets lyriske elementer. Både for den tyske filosof G.W.F. Hegel og for Francesco de Sanctis, 1800tallets største italienske litterat og forfatter til den epokegørende Storia della letteratura italiana (»Den italienske litteraturs historie«, 1871) er de episke elementer i Liberata således udvendige og kunstnerisk mislykkede. Værkets egentlige kvaliteter ligger ifølge De Sanctis i stedet i en inderlig og melankolsk generindring af en fordrømt ridderverden. ${ }^{16}$ For så vidt som den har været optaget af genrespørgsmål er de sidste tredive års kritik gået bort fra forestillingen om lyriske elementer i Liberata. Til gengæld har man fokuseret på de måder, den episke genre ligger i en produktiv indre konflikt med de mange spor efter den tidligere renæssances ridderdigtning, som man også finder i Tassos hovedværk - heller ikke her tages værkets genreprædikat for pålydende. ${ }^{17}$ 
De forskellige tiders diskussioner af Liberatas genremæssige placering er selvsagt påvirkede af forandringerne i vores opfattelse af, hvad en litterær genre er. For senrenæssancen og klassikken udgjorde de teoretiske forestillinger om genrernes ideelle udseende en målestok for æstetisk kvalitet, hvorfor spørgsmålet om, hvorvidt Tassos hovedværk var et epos eller ej i virkeligheden var en diskussion om værkets litterære kvaliteter og mangler. Både romantikkens og vor tids kritiske diskussioner af Liberatas genremæssige placering er derimod indskrevet i en vag, men udbredt genreteoretisk tradition, der anskuer de litterære genrer som semantisk ladede former, hvis opkomst, bortsvinden og symbolske gehalt knytter an til givne, historiske epoker. Særligt de narrative storformer, romanen og epikken, er de sidste 200 år blevet opfattet som en art litterære troldspejle, hvori en tids forestillinger om den omgivende verden kommer til udtryk.

Denne forestilling løber tilbage til den tyske idealisme og får sin mest prægnante udformning i Hegels Vorlesungen über die Ästhetik. Det skal med, at Hegels genrebegreb er dobbelt: de litterære genrer er for ham på en gang litteraturhistoriske fænomener og transhistoriske udsigelsesmæssige modaliteter. Således definerer Hegel i første omgang epikken som den genre, hvorigennem enhver given epokes bevidsthed om sin omverden kommer til udtryk. Men som følge af forestilling om verdensåndens historiske vandring mod selvbevidsthed er den æstetiske gestaltning af en på en gang »objektiv« og ureflekteret omverdensbevidsthed ifølge Hegel kun fuldt og helt mulig i det førklassiske Grækenland. Skønt epikken på et plan er dén genre, der udsiger enhver given epokes bevidsthed om verden, så er den altså også, som symbolsk form, knyttet til én bestemt historisk epoke, for hvilken den er det adækvate æstetiske udtryk. Af samme grund er Hegel kritisk over for den europæiske klassiks forsøg på bevidst at genoplive genren, den bevidste genoptagelse udtrykker nemlig en selvbevidsthed, der for Hegel er genren fremmed. ${ }^{18}$

Den hegelianske genreopfattelse har på mange måder domineret receptionen af Liberata. Francesco de Sanctis tolkede således Tassos genoptagelse af den klassiske epik som en æstetisk parallel til det italienske folks udvendige accept af, men ikke egentlige tro på den katolske tros former under modreformationen. Og selv om senere tolkninger nok har forbehold over for detaljerne i De Sanctis analyse, så har de ikke rørt ved dens grundlæggende præmisser. I sin banebrydende L'uniforme Cristiano e il Multiforme Pagano (»Den kristne enhed og den hedenske mangfoldighed«, 1979), tolker Sergio Zatti således entydigt Tassos forsøg på at skrive et klassisk epos som det æstetiske korrelat til modreformationens omverdensforståelse. Samtidig lader Zatti den italienske renæssances ridderdigtning inkarnere den tidligere renæs- 
sances ånd, hvorfor Tassos værk, hvis æstetiske værdi ifølge Zatti opstår i spændingen mellem de to genrer, skulle inkarnere den mentale spænding mellem renæssancens dennesidige verdslighed - og modreformationens religiøse dogmatik. ${ }^{19}$

Hos Zatti (der på dette punkt er repræsentativ for store dele af Liberatas receptionshistorie) er de to genrer altså entydigt æstetisk-symbolske korrelater til epokalt forankrede omverdensforståelser. Hvor udbredt den end er, bør en sådan genreopfattelse imidlertid ikke blot kritisk nuanceres. Den bør lodret afvises, eftersom den ved nærmere eftersyn analytisk viser sig reduktiv og upræcis, og teoretisk går fejl af de litterære genrers begrebslige status. Det første kan ses i forhold til Liberata. Historisk set er det nemlig upræcist at tolke 1500 tallets bølge af normative regelpoetikker og fascination af den episke genre som en æstetisk pendant til den katolske kirkes religiøse dogmer. Et er, at De Sanctis ligning: æstetisk dogme = religiøst dogme bygger på en problematisk romantisk grundtanke om, at digtningen bør udtrykke digterens - subsidiært tidens - åndelige gehalt. Ser man nærmere efter, er der også en betydelig historisk afstand (ca. 20 år) mellem de første, genreteoretiske diskussioner af den episke genre i Italien og den katolske kirkes implementering af modreformationens kristne hegemoni. ${ }^{20}$ Ydermere står den nærmere forbindelse mellem det klassiske epiks former og modreformationens syn på verden hen i det uvisse. Faktisk er der alt andet end sammenfald: den klassiske epiks tematiske og narrative repertoire blev fastlagt i en græsk-romersk, ikke i en kristen kulturkreds. En analyse af senrenæssancens genoptagelse af det klassiske epos bør derfor snarere tage højde for genrens grundlæggende »fremmedhed « i forhold til det kristne Europas kulturelle og sociale horisont. Man bør f. eks., som denne artikel, spørge til fremstillingen af kristendommens religiøse magter i Liberata. Hvordan påvirker det deres gestaltning, at de skrives ind i et genremæssigt forlæg, hvis topoi og narrative struktur er udviklet med udgangspunkt i den græsk-romerske pantheon?

Ovenstående er en pragmatisk kritik. I sin bog Qu'est-ce qu'un genre littéraire og især i artiklen »Literary Genres and Textual Genericity« viser den franske semiotiker Jean-Marie Schaeffer, at ideen om genrerne som symbolske former - en idé, hvis opkomst han placerer i den tyske idealisme, men i øvrigt finder udbredt i størstedelen af det tyvende århundredes genreteori ikke kun er upræcis, den går også fejl af de litterære genrers logiske status. ${ }^{21}$ De forskellige genrebetegnelser udgør ifølge Schaeffer ikke et sæt af begreber, man post factum kan bruge til at skabe en vis orden i mængden af litterære værker, ej heller er de selvstændigt eksisterende og semantisk ladede former, det enkelte værk mere eller mindre stemmer overens med. Genrerne er derimod virksomme som forestillinger inden for en litterær tradition. De 
er forestillinger, den enkelte forfatter med sine værker forholder sig til, afviser, skriver sig ind i eller op af - og forandrer. Den genreorienterede analyse bør derfor undersøge, hvordan de litterære værker positionerer sig i forhold til de litterære genrer, sådan som man forestillede sig dem i værkets samtid. Den bør undersøge, hvordan litteraturen forvalter de litterære genreforestillinger, og hvordan denne forvaltning indvirker på værkets endelige udformning. Hvad den derimod ikke bør gøre, er med strukturalismen at stille sig tilfreds med at bestemme hvilken genre, undergenre eller genrehybrid et værk måtte tilhøre eller med romantikken forfalde til at betragte genrerne som fænomener, der eksisterer uafhængigt af de enkelte værker.

En analyse af de litterære værkers genreforvaltning kompliceres ifølge Schaeffer af genrebetegnelsernes noget rodede referens. For faktisk henviser en given genrebetegnelse på et og samme tidspunkt til flere forskellige fænomener. En genre - »epos« - er betegnelsen for en samling litterære værker (de homeriske eper, Vergils Eneiden med videre), men navnet betegner også en mere eller mindre diffus viden om genrens typiske udseende, samt en given tids eksplicitte, formaliserede forestillinger om, hvad der er og bør være genrens karakteristiske særtræk. Den enkelte genrebetegnelse fungerer således som en taksonomisk kategori, men betegner samtidig en ikke-formaliseret vidensfond og en ideel forestilling. Og disse tre betegnede fænomener behøver ikke at stemme overens, gør det tværtimod sjældent: som følge af forandringer i de kritiske forestillinger - og som følge af taksonomiernes historiske træghed - ender man ofte i situationer, hvor de eksemplariske værker for en given genre ikke passer til de ideelle forestillinger, man har om samme genre. Eller hvor der ikke er megen sammenhæng mellem en given tids implicitte forestillinger og ekspliciterede normer i forhold til en given genre.

Don Quixote betegnes i dag som en roman, endda som en af litteraturhistoriens vigtigste romaner; skulle man beskrive den typiske roman i dag, ville beskrivelsen ikke desto mindre ligge langt fra Don Quixote. Et andet - i denne sammenhæng mere relevant - eksempel er senrenæssancens forhold til den antikke epik. Skønt man opfattede Eneiden og Illiaden som den episke genres højdepunkter, udtrykte tidens normative genrepoetikker refleksioner over den episke genre, som var disse fremmede; eperne indeholder til gengæld træk, poetikkerne kun sjældent forholder sig til. Når Tasso genoptager det klassiske epos i senrenæssancen, går han altså i dialog med og bliver påvirket af såvel antikkens eper som sin samtids genrerefleksioner. Som det følgende afsnits korte gennemgang af 1500tallets æstetikteoretiske horisont med al tydelighed viser, er de to ting ikke det samme. 


\section{Aristoteles og senrenæssancens genreteorier}

Det italienske 1500-tals æstetikteoretiske horisont og især periodens forhold til den klassiske litteratur blev helt og fuldt domineret af genopdagelsen af Aristoteles’ Poetik. Til forskel fra Aristoteles øvrige værker spillede poetikken ikke nogen rolle for middelalderens skolastikere, faktisk var værket knap nok kendt i slutningen af 1400-tallet. Til gengæld vandt det så meget desto større udbredelse fra og med 1530 'rne. ${ }^{22}$

Nu skal receptionen af Aristoteles' Poetik ikke blandes sammen med den langt tidligere genopdagelse af antikkens litterære arv. Denne var, i al fald delvist, kendt op gennem hele middelalderen - et eksempel er Vergils betydning for Den Guddommelige Komedie og den klassiske prosas betydning for den tidlige renæssances opgør med middelaldermunkenes latin. Men 1500-tallets genopdagelse af Aristoteles' Poetik forandrede den måde, man i senrenæssancen diskuterede og forstod det litterære værk og de litterære genrer. I sin bog La sottigliezza del disputare påpeger Hermann Grosser således, at tidens mange genrediskussioner - som udsprang af læsninger af Aristoteles Poetik - bør ses som en markant fornyelse i forhold til den tidligere renæssances tradition for at imitere de antikke klassikere. Hvor man tidligere imiterede passager, topoi og stiltræk fra en eller flere udvalgte antikke forfattere, det være sig Vergil, Cicero eller Seneca, så reflekterede man fra 1500-tallets midte og fremefter over de litterære genrers ideelle udseende - og søgte derudfra at skrive værker, der var på højde med, måske endog bedre end antikkens. ${ }^{23}$ Man ophørte med blot at betragte de antikke eper som efterlignelsesværdige værker: i sedet betragtede man dem som eksempler på en antik, efterlignelsesværdig genre.

Forskydningen er subtil, men afgørende, og har ikke blot en kritikhistorisk, men også en praktisk side. Ud af den nye genreforståelse sprang nemlig senrenæssancens mange og bevidste forsøg på at genoptage den episke genre. Receptionen af Aristoteles resulterede således både i en mængde normative genrepoetikker, der kan minde om vores værste forestillinger om den franske klassiks pedanteri, men som blev skrevet små hundrede år før denne - og i en række forsøg på at skrive moderne, »antikke« eper. Det skal med, at tidens genrepoetikker underlagde disse nye eper en række normative krav, der blev udledt af Aristoteles eller hentet fra Horats Ars Poetica, men som ikke havde meget med den historisk forekommende, antikke epik at gøre, og såmænd heller ikke med de spredte kommentarer Aristoteles vier den episke genre i sin Poetik. Kravet om den episke handlings enhed stod f. eks. centralt i senrenæssancen - og det krav kan Homer og Vergil ikke leve op til, og Aristoteles vel heller ikke skrive under på. 
Det skal også med, at den episke genre indtog en noget speciel position i senrenæssancens litteratur. Til forskel fra Aristoteles, som foretrak tragedien, fandt 1500tallets italienske litteraturteoretikere generelt, at epikken var den mest perfekte af de litterære genrer. ${ }^{24}$ Desværre fandtes der ingen værker på folkesprogene, der meningsfuldt kunne læses som tidligere eksempler på denne 'perfekte' genre. Ariostos Orlando Furioso - og i videre forstand renæssancens mange ridderdigte - var det tætteste man kom på en egentlig epik i Italiens hidtidige litteratur. Men selv om de nok fortalte om riddere på eventyr og højstemt kærlighed, så brød de på afgørende punkter med de nye genrepoetikkers normativt opsatte forskrifter. Ridderdigtene var fyldt med fantastiske, usandsynlige hændelser, blandede grovkomiske scener med højstemte passager, overholdt ikke kravet om handlingens enhed og indeholdt ofte ironiske kommentarer fra fortællerrøsten. Alt sammen grunde til at de, deres popularitet og øvrige kunstneriske kvaliteter ufortalt, ikke kunne leve op til genrepoetikkernes nye/gamle litterære ideal. ${ }^{25}$ Selv om epikken var den højest valoriserede genre i den italienske senrenæssances litteratur, eksisterede den altså ikke som en del af samme litteraturs hidtidige praksis. Forsøget på at skrive 'rigtige' eper var altså nok en tilbagevenden til en antik genre, men den udtrykte samtidig et brud med den eksisterende litterære tradition.

I perioden omkring 1550 udkom en række forsøg på at skrive klassiske eper på italiensk - mest kendt er nok Giangiorgio Trissinos Italia Liberata dai Goti fra 1549. Disse viste sig at være kunstnerisk mislykkede og fik da heller ingen succes hos publikum. Var de moderne, klassiske eper æstetikteoretisk korrekte, så synes de kunstneriske kvaliteter (og publikum) således forbeholdt de 'ukorrekte' italienske ridderdigte, for samtiden inkarneret i Orlando Furioso. Tasso, der blev født i 1544 og planlagde hovedtrækkene i Liberata inden sit tyvende år, begyndte således sin litterære karriere på et tidspunkt, hvor refleksionerne over den episke genre var en fast etableret del af det litterære felt, men hvor det også stod klart, at genoptagelsen af samme genre ikke var uden problemer. Det påvirker hans eget episke forsøg, såvel som hans teoretiske refleksioner, som han formulerede i skriftet Discorsi dell'arte poetica.

\section{Det fantastiske og det sandsynlige}

Discorsi dell'arte poetica blev trykt første gang i 1587, men havde formodentlig fundet sin overordnede form allerede i $1562 .{ }^{26}$ På mange måder er skriftet typisk for tidens genrepoetikker. Det blander ureflekteret diskussioner af 
digtningens væsen sammen med konkrete råd til, hvordan det 'ideelle' epos bør formes, og er samtidig stærkt påvirket af Aristoteles. Enkelte passager er direkte oversat fra hans Poetik, hvorfra også store dele af begrebsapparatet er hentet.

Ikke desto mindre er indholdet temmelig originalt. Ifølge Discorsi er det nødvendigt at iblande den episke genre træk og karakteristika fra samtidens italienske ridderdigtning, hvis man med succes vil modernisere den episke genre. Et epos skal selvsagt overholde de genrebestemte krav, man (og det vil sige Tasso) med hjælp fra Aristoteles kan udlede for dets udseende. Men man må samtidig tage hensyn til det publikum, man skriver for. Et moderne epos bør derfor tage form som en syntese af det bedste fra de to litterære traditioner: den antikke epiks æstetikteoretiske perfektion og ridderdigtenes evne til at henrykke det italienske publikum.

Når en sådan syntese ikke fører til en genremæssig bastard skyldes det ifølge Tasso to ting. For det første påpeger han, at de italienske ridderdigte $\mathrm{i}$ virkeligheden ikke udgør en egen genre. Snarere er de 'ukorrekte' eper, eller rettere: episke værker, der på visse områder ikke overholder normerne for genrens ideelle udseende, men på andre nok kan være en inspirationskilde. For det andet sondrer Tasso mellem de træk ved et kunstværk, der er bestemt af dets natur (et epos bør f. eks. grundet dets natur skrives i høj stil og skal af samme grund overholde handlingens enhed) og de mere eller mindre kontingente træk, der er bestemt af den tid, værket er skrevet ind i. Og hvad angår de sidste, så bør man faktisk ikke efterligne antikken, men derimod hente inspiration i den italienske ridderdigtning. ${ }^{27}$ Således skal et moderne epos selvsagt efterleve de æstetikteoretiske krav, der er udledt af den episke genres natur, og som man kan se virkeliggjort i de antikke eper. Men denne episke kerne bør dækkes af en moderne glasur, nemlig ridderdigtningens.

I praksis - og det vil her sige i Discorsis forsøg på at udrede, hvilke træk ved den episke genre, der er essentielle, og hvilke der er historisk kontingente - er samspillet mellem den eksisterende litterære tradition, de opsatte litterære idealer og efterligningen af de antikke eper noget mere indviklet. Ganske vist kan Tasso uden problemer fastslå, at det er upassende at kopiere slagscener med græske stridsvogne ind i et epos, der foregår i Europas middelalder. Men som allerede nævnt stod mange væsentligste karakteristika i ridderdigtningen i et nærmest antitetisk modsætningsforhold til Discorsis - og mere generelt senrenæssancens - normer for det ideelle epos. Ikke blot regnedes handlingens enhed for et uomgængeligt krav til det 'perfekte' epos, altimens episodernes varierede mangfoldighed netop var det, der gjorde Orlando Furioso så populær i sin samtid. Ideelt set skulle epikken ikke kun tage udgangspunkt i historiske begivenheder, den skulle også - og først og 
fremmest - overholde kravet om det gestaltedes sandsynlighed. Ridderdigtene underholdt derimod deres publikum ved at fremstille fantastiske og mirakuløse, og det vil sige usandsynlige hændelser. ${ }^{28}$ De træk i ridderdigtene, der gjorde dem populære, var således netop dem, der brød med genrepoetikkernes spekulativt opsatte normer. Ikke desto mindre måtte behaget ved ridderdigtningen overføres til det nye epos, hvis dette skulle blive en kunstnerisk succes. Store dele af Tassos Discorsi går derfor med at udtænke litterære og retoriske greb, hvormed ridderdigtenes populære svinkeærinder kan indoptages i et moderne epos, uden at man derfor taber genrens æstetiske perfektion på gulvet.

I forhold til Liberatas gestaltning af Satan er Discorsis forsøg på at inkorporere fantastiske begivenheder inden for rammerne af en sandsynlig handlingsgang interessant. Tasso fastslår, at det fantastiske er en nødvendig ingrediens i epikken. »I sandhed er det digt, som ikke i sig har de vidundere [maraviglie], der bevæger ikke blot de uvidendes sjæle, men også de forstandiges, kun lidet fornøjeligt«, skriver Tasso - med en skjult hentydning til de tidligere forsøg på at genoptage den episke genre, som i deres rigoristiske applikation af de aristoteliske krav glemte hensynet til læsernes behag. ${ }^{29}$ Som eksempler på »il meraviglioso« nævner Tasso derefter skibe, der forvandles til feer, fortryllede ringe, magiske skjolde og flyvende heste: topoi fra såvel antikkens eper som renæssancens ridderdigte. Imidlertid kan man ikke længere lade de fantastiske hændelser fødes ud af en græsk-romersk pantheon, sådan som man gjorde i de antikke eper. Det er ikke troværdigt, eftersom man ikke længere tror på de antikke guder. Og hvad gør man så? Tasso har følgende løsningsforslag:

»Digteren bør tilskrive nogle begivenheder, som langt overstiger menneskenes evner, Gud, hans engle, dæmonerne eller dem, som er givet denne evne af Gud eller dæmonerne, hvilket er helgenerne, troldmændene og skæbnefeerne. Disse begivenheder, hvis de bliver betragtet for sig selv, vil synes fantastiske [maravigliose], og kaldes endog mirakler i almindelig tale. De samme begivenheder, hvis man holder sig dem for øje, der har udvirket dem, og disses evner og kræfter, vil anses for at være sandsynlige; fordi, eftersom vores folk har drukket denne opfattelse som spæde, sammen med mælken, og derefter fået den bekræftet af vores hellige tros mestre [...] og eftersom de hver eneste dag læser og hører omtale nye eksempler, vil det ikke synes dem hinsides det sandsynlige, som de ikke blot mener er muligt, men også anser for ofte at være sket og at kunne ske mange gange på ny. Sådan som også de antikke, der levede i deres indbildske tros fejltagelser, ikke anså de mirakler, 
som ikke blot poeterne, men nogle gange også historikerne fortalte om deres guder, for at være umulige. $\aleph^{30}$

Rådet er enkelt. Troen på, at de kristne religiøse magter og deres udvalgte kan udføre mirakler er en del af samtidens doxa - en tro, man har fået ind med modermælken, på samme måde som grækerne mente, at deres guder udførte mirakler. Ønsker man at forbinde de aristoteliske krav med renæssancens litterære smag for fantastiske begivenheder, må man lade disse magter optræde som figurer i epikken. Gud og Satan må optræde, eftersom de er garanterne for det fantastiskes troværdighed.

Det er værd at bemærke, at ovenstående citat anskuer brugen af religiøse figurer ud fra en specifikt æstetisk synsvinkel, og derved reducerer kristendommen til sæd og skik: spørgsmålet om, hvorvidt de religiøse overbevisninger er sande eller falske underordnes spørgsmålet om, hvorvidt de anses for at være sande. Nok er Tasso kristen. Og nok udtrykker Liberata som helhed en næsten fanatisk kristendom. Men i netop denne sammenhæng underordnes den teologiske ortodoksi af et æstetikteoretisk problemfelt. Citatet bekræfter således, at senrenæssancens regelpoetikker ikke er den æstetiske pendant til modreformationen. Tværtimod udtrykker den rigoristiske regeltænkning, i al fald her, den æstetiske refleksions begyndende selvstændiggørelse fra moral og religion.

I al fald: de kristne religiøse magter bør ifølge Tasso optræde i en moderne epik og der have samme æstetiske funktion, som de græsk-romerske guder havde i antikkens eper. I hans eget epos, Liberata, begrænser ligheden mellem de kristne og de græsk-romerske gudemagter sig imidlertid ikke til funktionen som æstetikteoretisk garant for det fantastiskes sandsynlighed. Der går mere i arv: helt i tråd med eksemplerne fra Discorsi er repertoiret af overnaturlige fænomener i Liberata taget fra både de antikke eper og ridderdigtningen, men ikke fra den kristne religions tradition for mirakuløse helbredelser og 'magiske' helgenrelikvier. Ydermere er værkets narrative brug af de religiøse magter - Gud og Satan hjælper hver sin part i en episke krig, der er centreret omkring belejringen og erobringen af en by - helt tydeligt taget fra Illiaden og Eneiden.

Skønt kristne agerer de himmelske og djævelske magter i Liberata altså med midler, der synes dem fremmede. Og de gør det inden for narrative skemaer, der er hentet fra den klassiske episke genre. Bestemmer koblingen mellem de æstetiske begreber fra Aristoteles og tidens smag for ridderdigte, at Satan skal optræde som gestaltet figur, så synes den form, han er gestaltet i, bestemt af den antikke, episke tradition. Og det rejser naturligt spørgsmå- 
let: er Satan-skikkelsen i Liberata figureret som en græsk-romersk gud, sådan som disse så ud i de antikke eper?

\section{Satan på olympens tinder}

Svaret er ja ... og så alligevel ikke. Indledningsvis er det påfaldende, at Juno i Eneiden, hvor hun som bekendt er gud for den tabende part, i sin placering og narrative funktion minder påfaldende om Satan i Tassos hovedværk. I Eneiden har hun rollen som den guddommelige modstander, der til stadighed prøver at forhindre Æneas i at nå den episke fortællings mål, grundlæggelsen af et nyt Troja. På samme måde prøver Satan at forhindre korsridderne i at erobre Jerusalem. Junos forsøg mislykkes til slut, og Fneas ender som stifter af romerriget. Men inden da formår hun at lægge endog betydelige hindringer i vejen for ham - helt som de djævelske magter, der ender med at spille fallit i Liberata, men i størstedelen af handlingen faktisk forhindrer erobringen af Jerusalem. Ydermere: som de andre guddomme i de klassiske eper taler Juno altid før hun agerer. Et eksempel finder man i begyndelsen af Eneidens første sang, hvor hun fyldes med vrede over, at Fneas endnu ikke er bukket under på sin rejse - og siger:

»Skal jeg give op og se mig besejret og ikke mægte at holde Trojanernes drot fra Italiens strande!

Skæbnen er mod det - javist! Har en Pallas da kunnet knuse

Grækernes flåde og drukne dem selv - og det for en brøde

Ajax, Ö̈leus søn, var alene om i sit vanvid! [...]

$J e g$, der er Gudernes dronning og Juppiters søster og hustru, jeg skal i så mange år føre krig med blot dette ene folk! Er der så mon nogen der siden vil tilbede Junos magt eller bøje sig for hendes alter og bringe det ofre? «11

Ikke blot henvisningen til den egne kultus vækker mindelser om Satans tale i Liberata (»Skal vi finde os i ... at vores gudebilleder skal være spildte? at verden bruger vores altre til Hans ære?«, IV, 14). Også Satans hyppige brug af retoriske spørgsmål genfindes og er i øvrigt typisk for guderne i Eneiden. Samtidig viser passagen med al ønskelig tydelighed, at gudernes taler er det sted i de klassiske eper, hvor de udtrykker både deres reaktioner på den episke handlingsgang og deres syn på verdens generelle tilstand. Her motiverer 
guderne de handlinger, de dernæst udfører, her præsenterer de deres syn på forskellige, relevante begivenheder fra fortiden.

Bør man glæde sig over eller begræde, at Troja faldt? Alle andre overlevende trojanere har fundet nye hjem, er det så retfærdigt, at Eneas stadig skal flakke hjemløs rundt? I Eneiden inddrages fortidens begivenheder som retoriske argumenter for nutidige indgreb i menneskenes verden. Når Satan henviser til Guds tidligere overgreb og motiverer sin støtte til muslimerne med henvisning til fortidens uretfærdigheder, så gentager han altså en fast figur fra de klassiske epers gudetaler, nogenlunde det samme gør hans narrative funktion som modstander i den episke krig. I den forstand er Tassos Satan-skikkelse kalkeret efter et græsk-romersk forlæg. I Liberata er Satan aftegnet med former, hentet fra en klassisk episk tradition - og det vil sige former, der er udviklet omkring guder fra en ikke-kristen kulturkreds.

Faktisk peger en række ord og vendinger i passagen fra Liberatas fjerde sang tilbage mod den romerske kulturarv. Således kaldes Satan for »Plutone» $(\mathrm{IV}, 6)$, navnet på kongen over dødsriget i den romerske mytologi. I sin tale til dæmonerne kalder Satan dem for »tartarei numi« (IV, 9). »Tartaros« er navnet på den romerske underverden, "nume« (guddom) stammer etymologisk fra latin. Og Tassos katalog over beboerne i helvede opremser en række af de kendteste uhyrer fra den græsk-romerske mytekreds - til gengæld mangler de kristne djævle, der med horn i panden piner de fordømte sjæle:

»Her ville du se tusinder af urene Harpyer og tusinder Kentaurer og Sfinxer og blege Gorgoner; mange og mange Skyllaer gø, og Hydraer pibe og Pythoner hvisle og Kimærer udspy mørke flammer og forfærdende Polyfemer og Geryoner; og i nye monstre, og i monstre som ikke længere kendes eller ses, er forskellige udsender blandet og rodet sammen i et. $«^{32}$

At Tasso kalder Satan for »Plutone« og lader ham herske over en samling af uhyrer peger imidlertid også på, at Satan-skikkelsen i Liberata nok er formet ud fra et græsk-romersk forlæg, men ikke af den grund er en direkte kopi af en af Olympens guder. I den antikke mytologi har Pluto/Hades nemlig aldrig noget udestående med epernes helte, det har kun de guder, der forbinder sig til de levendes verden: Juno, Venus, Pallas Athene, Neptun, Jupiter. Og ser man nærmere efter, finder man en række andre markante forskelle mellem Liberatas Satan og den antikke epiks prototypiske gudeskikkelse. Selvsagt forsones Gud og Satan ikke i slutningen af Liberata; i slutningen af Eneiden forsoner Juno sig derimod med Jupiter og skæbnen. ${ }^{33}$ Der er ingen scener i Liberata, der svarer til de i de klassiske eper, hvor guderne (også de guder, 
der hjælper hver sin side i den episke krig) disputerer med hinanden. Endelig bibeholder Liberata kristendommens absolutte moralske modsætning mellem Gud og Satan. Også her er Satan ondskaben selv - hvorimod de olympiske Guder hverken synes onde eller gode, men blot for eller imod de episke helte.

Overtagelsen af det genremæssige forlæg er altså ikke total, men delvis. Skønt gestaltet efter topoi, der er beregnet til en anden type guddomme, forbliver Tassos Satan indskrevet i en kristen, teologisk forståelsesramme, hvorfor han - sin tale til trods - stadig er »de menneskelige folks store fjende« ( $\mathrm{Li}$ berata IV, 1). De træk fra de klassiske epers fremstilling af guderne, der går ret imod den kristne teologis grundsætninger, undertrykkes, andre forskydes, så de passer bedre ind i en kristen forståelsesramme, og andre igen forandres som følge af tidens æstetikteoretiske refleksioner. Tassos gestaltning af Satan er resultatet af en forvaltning af den klassiske epik, produktet af epikkens indpodning på en kultur, for hvem den var fremmed, snarere end en direkte kopi af den episke genres indlejrede topoi.

Det betyder også, at Satan-skikkelsen i Liberata ikke er udtryk for et direkte brud med de kristne forestillinger om Satan, men videreudvikler og accentuerer træk, der allerede lå i det, jeg har kaldt Satan-som-Lucifer. Ikke desto mindre udgør Liberatas Satan en markant fornyelse i de måder, hvorpå den kristne djævel er blevet fremstillet i litteraturen.

\section{Genesis og reception}

I Liberata fremstilles Satan for første gang i den europæiske litteratur som en storslået, reflekteret oprører mod den guddommelige magt. Ovenstående analyse viser, at denne litterære fornyelse opstod i samspillet mellem senrenæssancens æstetikteoretiske refleksioner, arven fra de klassiske eper, den italienske litterære tradition og, men blot som én blandt flere faktorer, den italienske senrenæssances politiske og religiøse horisont. Litterære værker knytter imidlertid ikke kun an til historien i deres genesis. Bevægelsen går også den anden vej: fra det litterære værk og til en omgivende kultur. En undersøgelse af Liberatas Satan-skikkelse synes derfor at være halv, hvis man ikke også tager et - i det mindste kursorisk - kig på figurens receptionshistorie.

Tassos Liberata blev en af senrenæssancens største litterære succeser, også internationalt - værket var inden år 1600 oversat til engelsk, tysk og spansk. ${ }^{34}$ Samtidig udviklede diskussionen om, hvorvidt Liberata levede op til de æstetikteoretiske fordringer man kunne finde hos Aristoteles, sig til en bitter lit- 
terær fejde. Kritikken af Liberata koncentrerede sig imidlertid om mængden af fantastiske hændelser i bogen; om Tassos forsøg på at sammenføje handlingens enhed med episodernes mangfoldighed; og om bogens manglende stilistiske og moralske perfektion - gestaltningen af Satan pådrog sig ikke større opmærksomhed i samtiden. ${ }^{35}$ Til gengæld har den påvirket senere litteratur. Indflydelsen fra Tassos Satan er f. eks. tydelig i John Miltons genfortælling af syndefaldet, Paradise Lost (1667).

Man ved, at Milton læste og kendte til Tasso. Mængden af intertekstuelle referencer i Paradise Lost er imidlertid så frygtindgydende, at man ikke entydigt kan bevise indflydelsen fra Liberatas fremstilling af Satan. Ydermere er Satan hovedpersonen hos Milton, hvorfor han optræder i en række scener, hvor Tassos værk med sikkerhed ikke spiller nogen rolle som forlæg. Ikke desto mindre har Miltons Satan en påfaldende lighed med Satan-skikkelsen i Liberata, og det især i de første to sange af Paradise Lost. Her fremstiller Milton entydigt Satan som en Luciferskikkelse, ikke som en frister af mennesket. Og også Miltons Satan ønsker aktivt, talende og reflekteret at gøre oprør mod Gud, selv efter sit fald fra himlen. Ligesom i Liberata indledes Satans fortsatte kamp mod Gud i Paradise Lost med en tale til forsamlingen af djævle i helvede. Og som hos Tasso gestaltes Satan i Paradise Lost som en på en gang storslået og tåbelig skikkelse.

Vender man sig mod de to Satan-skikkelsers selvforståelse, så er der slående paralleller. Både hos Milton og Tasso taler Satan om æren ved at have forsøgt - og finder i viljen til at gøre oprør tegnet på, at kampen mod Gud endnu ikke er tabt. ${ }^{36}$ Samtidig er der slående paralleller i deres forståelse af de himmelske magter og deres egen placering i helvede. »Nu hersker Han som Han vil over stjernene, og vi anses for at være oprørske sjæle « ${ }^{37}$, siger Tassos Satan; Miltons betegner Gud som en, „Whom reason has equall'd, force made supreme/ Above his equals. $\aleph^{38}$

Begge værkers Satan-skikkelser anerkender nok Guds overlegenhed, men undsiger den i samme bevægelse. Gud er nok mere magtfuld end Satan, men han kan ikke begrunde sit overherredømme med andet end sin egen magt som sejrherre i en kosmisk krig, hvorfor de dømte engles fald hverken skyldes nogen dybere retfærdighed eller en legitim sondring mellem godt og ondt. De er blot, som Liberata skriver, blevet dømt oprørske. I den forstand udtrykker citaterne fundamentet for Satans selvforståelse i såvel Liberata som Paradise Lost. De er samtidig et stærkt indicium for, at inspirationen fra Tasso har spillet en afgørende rolle for Miltons Satan-skikkelse - uden at jeg dermed vil underkende de forskelle, der også er.

Paradise Lost overtager og videreudvikler de fornyelser i fremstillingen af Satan, som man finder i Liberata. Og Miltons Satan fik stor betydning for den 
engelske romantik. ${ }^{39}$ Stærkt inspireret af Milton anskuede romantikerne, især Blake, Shelley og Byron, nemlig Satan-som-Lucifer som en art forløber for den romantiske digter, som inkarnationen af kreativitetens nødvendige oprør mod det bestående. Ligesom Miltons Satan er storslået i sin vilje til oprør, er digteren storslået $\mathrm{i}$ sin vilje til at bryde med en stivnet og filistrøs borgerlighed. Og det er han uagtet, at dette oprør lider nederlag - han er det på det nærmeste, fordi hans oprør slås ned - eftersom viljen til forandring er det afgørende for romantikerne.

Man må også her fastholde, at ligesom Milton ikke kun kopierer Tasso, men også reaccentuerer dennes figuration af Satan, så overtager romantikerne ikke blindt Miltons gestaltning. De omtolker den også - visse træk videreudvikles, andre undertrykkes. Der er således intet tåbeligt over den romantiske Satan-som-Lucifer, selv om deres vurdering af ham kan være ambivalent. ${ }^{40}$ En måske vigtigere forskydning er, at Satan-skikkelsen med romantikken bevæger sig fra at være en litterær (og religiøs) figur til også at give form til digternes selvforståelse i forhold til den omgivende kultur. Således ender Satan-som-Lucifer (og det vil sige: reaccentueringen af denne skikkelse, som den er opstået hos Tasso og videreudviklet hos Milton) i romantikken som en art positiv rollemodel for den utilpassede digter. En udvikling, der eksemplificeres af Byrons selviscenesættelse som dæmonisk, aristokratisk romantiker - på en gang sublim og fordømt. I den forstand tager romantikken det endelige skridt i Satan-skikkelsens narrative frisættelse, som Liberata indledte. Med romantikken er skikkelsen helt løsrevet de scener og de replikker han blev tildelt i kristendommen - dæmonien og den sublime ondskab hænger selvsagt ved.

Samme frisættelse gør det nødvendigt at inddrage 1800-tallets kulturelle og sociale horisont, deriblandt romantikernes opgør med et begyndende industrisamfund og en utilitaristisk fornuftstænkning, i en egentlig analyse af den romantiske Lucifer-figur, hvilket er gjort før og i øvrigt ville føre for vidt. Imidlertid er påvirkningen fra den litterære model og til romantikernes selvforståelse lige så vigtig som de forandringer, samme model undergår, idet den forskydes ind i et bredere kulturelt felt. Og det synes tydeligt, at Miltons gestaltning af Satan - udover at inspirere en række af romantikkens litterære udgaver af den kristne djævel - også stod til rådighed for romantikerne i deres jagt på en adækvat semantisk figur til fortolkningen af deres egen sociale og kulturelle position. Sagt på en anden måde: romantikerne gør ikke blot brug af, men bliver i sidste instans formet af deres selvfiguration i den miltonske Satans tegn. I den sammenhæng er det påfaldende, at romantikerne greb fat i netop de træk hos Milton, som man allerede fandt hos Tasso. Også den romantiske Satan har sit eget perspektiv på verden, nemlig romantiker- 
nes egen. Også romantikerne anskuer Satan som en reflekteret, aktiv oprører mod det bestående, og det netop fordi denne orden set fra hans perspektiv ikke er retfærdig. Også romantikerne betoner den stadige vilje til oprør som det genuint storslåede ved skikkelsen. Og også hos romantikerne bibeholder Satan-skikkelsen en særlig moralsk tvetydighed, et stænk af ondskab, som man ikke finder i deres identifikation med den ellers parallelle Prometheusskikkelse.

Medieret gennem Milton ender de litterære fornyelser i Tassos Satan således som dele af et kulturelt tegn, hvis virkefelt ikke blot er litteraturen, men også en bredere kulturel horisont, og som i løbet af det nittende århundrede bliver én af de (mange) måder, digtere, bohemer og andre socialt og kulturelt utilpassede intellektuelle figurerer sig selv. Denne udvikling var selvsagt ikke forudset - formentlig heller ikke ønsket - af Tasso selv. Dens udgangspunkt er ikke desto mindre Liberatas gestaltning af Satan, en gestaltning, der opstod af helt andre grunde.

\section{Klassicisme, genreteori, litteraturhistorie}

Vender man sig fra den konkrete analyse, peger de litterære fornyelser i Tassos Satan-skikkelse på tre mere almene konklusioner. Den ene er litteraturhistorisk og handler om vores vurdering af klassicismen som litterær periode. De to andre er teoretiske og handler dels om de litterære genrer, dels om forholdet mellem litteratur og historie.

Gestaltningen af Satan er et eksempel på de litterære fornyelser, der opstår som følge af Tassos forvaltning af den klassiske epik, men det er selvsagt ikke det eneste sted, den episke genre indvirker på udformningen af Liberata, og heller ikke det eneste sted, hvor denne indvirkning fører til markante litterære fornyelser. ${ }^{41}$ I et bredere litteraturhistorisk perspektiv antyder disse, at senrenæssancens og klassicismens normative genreforståelse og mange genrepoetikker bør forstås som andet og mere end eksercitser i abstrakt og kunstfremmed regelrytteri, sådan som den tyske idealismes afvisning af den franske klassik ellers har lært os. De forskellige poetikkers konkrete påbud kan i dag synes noget mærkværdige, og man misforstod ganske givet centrale passager hos både Aristoteles og Horats. Ikke desto mindre, og som Tassos Discorsi eksemplificerer, er genrerefleksionerne udtryk for etableringen af almene og specifikt litterære værdikriterier - de udtrykker den europæiske litteraturs første, forvirrede skridt henimod en institutionel og æstetisk autonomi. Som påpeget ovenfor er det et skridt, som foregår parallelt med og er påvirket af modreformationen, men som ikke blot udtrykker dennes mentale 
habitus - og som i øvrigt bedst kan forstås som en videreudvikling af (og opgør med) den tidligere renæssances tradition for imitatio. ${ }^{42}$

Ydermere medfører genoptagelsen af de klassiske genrer et betragteligt input af nye litterære scener og narrative skemaer i senrenæssancens litterære repertoire - en kulturimport fra den antikke kultur til senrenæssancens Europa, om man vil. I den forstand bidrog tidens normative genreæstetikker (måske uden at vide det) til at udvikle en lang række litterære fornyelser. I den sammenhæng er Tassos epos kun et eksempel ud af mange. Man kunne med fordel afprøve denne artikels metodiske perspektiv på andre værker fra Tassos samtid; mere alment synes en generel revurdering af senrenæssancen og klassicismen og dennes betydning for den senere europæiske litteratur på sin plads.

Analysen af Tasso viser samtidig, at man med fordel kan undlade at betragte de litterære genrer som symbolske former. Det er en forestilling, der medfører analyser, som synes besnærende i deres elegante evne til at koble litteraturens former sammen med historisk-epokale begreber. Ved nærmere eftersyn viser forbindelserne sig imidlertid upræcise, i værste fald direkte misvisende, og det både i forhold til den historiske kontekst og det enkelte værk. Det giver mere mening at fastholde med Jean-Marie Schaeffer at, at de litterære genrer først og fremmest er virksomme som begreber i litteraturens egen historie. Og - igen, med Jean-Marie Schaeffer - at påpege, at genrebetegnelserne ikke dækker over organisk sammenhængende former, men i stedet på én gang refererer til bestemte værker i den litterære arv og til deres tids forestillinger om, hvordan de forskellige genrer kan og bør se ud. De litterære genrers navne dækker over et konglomerat af traditioner og kritiske forestillinger, der historisk set er foranderlige og ikke samler sig til et kohærent hele-som oftest tværtimod.

Det betyder ikke, at genretermerne er tomme betegnelser. Som analysen af Tasso viser, dækker betegnelsen »epos« i senrenæssancens over en række topoi, temaer og stilistiske valg, der viser sig alt andet end ligegyldige for den endelige udformning af Tassos hovedværk. Men det betyder, at forholdet mellem genre og historie forandrer sig. Snarere end at være et begreb, der magisk knytter det litterære værk sammen med den kontekst, værket er skrevet ind i, så er forvaltningen af de litterære genrer én af de måder, hvorpå litteraturen knytter an til sin egen historie. Genrerne medierer ikke mellem litteratur og historie, i al fald ikke hvis historie forstås som værkets kulturelle og sociale horisont. Snarere peger deres eksistens på, at forbindelsen mellem det litterære værk og dets samtid er filtreret og forskudt af litteraturens egne, specifikke historier - uden derfor at være fraværende. 
$\mathrm{Nu}$ er litterære genrer kun er en af mange begrebstyper, der er virksomme i litteraturens egne historie. Ydermere svinger genreforestillingernes formative betydning fra periode til periode - i senrenæssancen var disse forestillinger centrale for de litterære værkers udformning, i dag har de ganske vist nogen betydning, men ikke mere end så mange andre begreber. Implicit i en revurdering af de litterære genrers status ligger imidlertid en ny model for forholdet mellem litteraturens historie og den omgivende kulturelle horisont - en model, som denne artikel har forsøgt at eksemplificere.

Selvsagt opstår de litterære værker ikke i et vakuum, og selvsagt indvirker den historiske kontekst på de litterære værkers udseende. Men denne indflydelse medieres af mekanismer, der er specifikke for litteraturens historie hvilket i senrenæssancen først og fremmest vil sige genopdagelsen af Aristoteles' poetik, genoptagelsen af de antikke genrer og refleksionerne over de litterære genrers ideelle udseende. Ydermere kan man, både når det kommer til de litterære genrer, men formodentlig også mere generelt, med fordel sondre mellem to distinkte mekanismer inden for litteraturens egne historie dels de af samtiden æstetisk satte krav til de litterære værker, dels dialogen med den litterære arv. De to mekanismer hænger sammen, men er ikke identiske, hvorfor deres indvirkning på værkernes endelige udseende heller ikke er det.

Det litterære værk påvirkes altså i sin genesis af faktorer, der er specifikke for litteraturens egen historie. Imidlertid kan de fornyelser, der opstår som følge af disse faktorer, udmærket påvirke den bredere kulturelle horisont $\mathrm{i}$ værkets samtid og i eftertid: som den uventede konsekvens af genoptagelsen af det antikke epos opstår en gestaltning af Satan, der efterfølgende udvikler sig til et alment kulturelt tegn. Afgørende er imidlertid, at de kræfter, der påvirker de litterære værker i deres genesis ikke spejles i samme værkers udsigelseskraft. ${ }^{43}$ Man kan derfor ikke antage, at det enkelte værks litterære fornyelser afspejler eller udgør fortolkninger af forandringer i det omgivende samfund. Det giver på den anden side heller ikke nogen mening at sige, at værkerne »handler om« dynamikken i litteraturens egen historie, også selv om denne dynamik har været en afgørende faktor for værkets endelige udseende.

Forbindelsen mellem litteratur og historie er således indirekte. De litterære værker er påvirket af og aktører i en bredere kulturel og historisk horisont, men giver ikke - i al fald ikke hvis ovenstående model står til troende - noget troværdigt vidnesbyrd om samme horisont. Med et blik på Tassos gestaltning af Satan kan man måske sige, at litteraturen altid er forud for og bagefter sin egen tid, men aldrig helt er på højde med den. 


\section{Appendiks: Gerusalemme Liberata IV, 1-18}

1. Mens disse er optaget af de store maskiner, fordi de snart skal tages i brug, vendte alle menneskers store fjende sine blysorte øjne mod de kristne; og da han opdagede, at de nu var muntre og tilfredse, bed han sig i læberne af vrede, og som en såret tyr gav han brølende og stønnende luft for sin sorg.

2. Derefter, da han har hele sin tankes kraft vendt mod at påføre de kristne størst mulig smerte, befaler han sit folk (forfærdende menighed!) at samles i det underjordiske rige; som om det var et let foretagende, ak hovmod!, at modsætte sig den guddommelige vilje: hovmodig er den, der gør sig til Himlens lige, og bevidst glemmer, hvordan Guds højre hånd tordner i vrede.

3. Den hæse tone af helvedes trompet tilkalder de evige skyggers beboere. De rummelige, mørke huler ryster, den blinde luft genlyder af rumlen; aldrig med et sådant brag falder lynet fra himlens øverste egne, aldrig skælver jorden med en sådan rystelse, når den gravid spærrer dampene inde i sit indre.

4. Snart samles Helvedes guddomme i flokkevis omkring de høje porte. $\mathrm{O}$, hvor mærkelige, o, hvor forfærdende skikkelser! hvor meget rædsel og død er ikke i deres øjne! nogle sætter dyriske spor, hvor de går, og bag et menneskeligt ansigt vrider sig slanger som hår, og bag dem kredser en umådelig hale, der som en pisk folder og snor sig.

5. Her ville du se tusinder af urene Harpyer og tusinder Kentaurer og Sfinxer og blege Gorgoner; mange og mange Skyllaer gø, og Hydraer pibe og Pythoner hvisle og Kimærer udspy mørke flammer og forfærdende Polyfemer og Geryoner; og i nye monstre, og i monstre som ikke længere kendes eller ses, er forskellige udseender blandet og rodet sammen i et.

6. Af alle disse går en del til venstre og en del til højre og sætter sig foran deres grusomme konge. Pluto sidder i midten og holder i højre hånd det tunge og grove scepter; hverken skærene i havet, bjergklipperne, eller endog Gibraltars klipper hæver sig så højt, ej heller den store Atlantkæde, som foran ham ville synes som små bakker, så højt hæver sig panden og de store horn.

7. Det vilde udseendes grufulde værdighed øger rædslen, og gør ham mere hovmodig: øjnene gløder rødt, og betændt af gift glimter blikket som en ulyksalig komet. Det store skæg dækker hans hage og falder stridt og krøllet ned ad det behårede bryst, og som en dyb afgrund åbner munden sig, uren af mørkt blod.

8. Ligesom svovlfyldte, antændte dampe - og stank og torden - kommer ud af Etna, sådan kommer fra den grusomme mund en sort ånde, sådan er stanken og flammerne. Mens han talte, holdt Kerberus sin gøen tilbage og Hydraen gjorde sig stum ved lyden; Cocito standsede sit løb og grotterne rystede; og i disse ord ville du høre den store drønen. 
9. »I Helvedes numier, mere værdige til at sidde over solen, hvor jeres oprindelse er, og som det store styrt engang sammen med mig skubbede fra de lykkelige riger ned i dette forfærdelige indelukke. Vores store forehavende, andres gamle mistanker og voldsomme harme er alt for kendte: nu hersker Han som Han vil over stjernene, og vi anses for at være oprørske sjæle.

10. Og i stedet for den rene og lykkelige dag, for den gyldne sol, for stjernernes vandringer, har Han lukket os inde i dette mørke dyb, ej heller vil Han, at vi stræber mod vor tidligere ære; og derefter (ak, hvor hårdt er det ikke at huske på det! det er det, som mest forbitrer mine martyrsmerter) har Han kaldt mennesket til himlens skønne sæder, det usle menneske, født af ussel mudder på jorden.

11. Og det synes Ham ikke nok; kun for at gøre mere skade gav Han sin søn som dødens bytte. Denne kom og brød helvedes porte og vovede at sætte fødderne i vor rige, og derfra tage sjæle, som tilhørte os som ejendom. Han bar rigt bytte til Himlen, hvor han som en triumferende sejrherre - til vores skam - fremviste beviserne på det overvundne Helvede.

12. Men hvorfor fornyr jeg mine smerter ved at tale? Hvem har ikke forstået de uretfærdigheder, vi blev udsat for? Og hvor man mødtes, og hvornår, for at han skulle ophøre med sine velkendte foretagender? Man bør ikke kun tænke på de gamle, vi må tænke på de nuværende overgreb. Åh! ser I ikke, hvordan Han søger at kalde alle folk tilbage til sin kult?

13. Skal vi da slapt henslæbe vores dage og timer, er der mon ikke en værdig bekymring, som tænder ild i vores hjerter? skal vi finde os i, at Hans tro folk for hver time der går vinder magt i Asien? og at de betvinger Judea? og at Hans ære, at Hans navn breder sig, strækker sig længere og længere? at det lyder på nye sprog, skrives i nye sange, mejsles i nye bronze- og marmorstøtter?

14. At vores gudebilleder skal være spildte? at verden bruger vores altre til Hans ære? at offergaverne gives, at røgelsen tændes, at guld og myrra ofres kun til ham? At dér, hvor templet ikke plejede at lukke sig for os, er der ikke længere nogen åben vej for vore kunster? at der af så mange sjæle mangler den fastsatte told, og at Pluto skal herske i et tomt rige?

15. Åh! det vil ikke blive sandt, for endnu er dén ånd ikke død i jer, som I viste dengang, da vi omringet af jern og høje flammer kæmpede mod det himmelske herredømme. Vi blev, jeg nægter det ikke, overvundet i det slag, og dog manglede der ikke mod i den store tanke. Hvad det end var, der gav ham sejren: længslen efter ære forblev ubesejret i os.

16. Men hvorfor nøler jeg længere? Drag afsted, o, mine trofaste fæller, o, min magt og kraft, gå hurtigt, og undertryk de onde, førend deres hære befæstes mere, førend hele jødernes rige brænder op. Lad denne voksende flam- 
me slukkes nu; træd ind iblandt dem, og anvend til deres størst mulige skade nu magt, nu list.

17. Lad det, som jeg ønsker, være skæbnen: lad nogle vandre spredt og forvildet rundt, nogle ende op døde, nogle dykke ned i den vellystige kærlighed, gøre sig afgudsbilleder af et smil og et kælent blik. Lad hæren, oprørsk og splittet, vende sine våben mod sin leder: lad lejren gå til grunde i ruiner og lad ethvert spor efter den ødelægges med den selv.«

18. De oprørske sjæle ventede ikke på, at disse ord var først til ende; men de forsvandt allerede nu fra den dybe nat, fløj ud og genså stjernerne ligesom larmende og urolige storme, der kommer ud af deres hjemstavns grotter for at formørke himlen, for at føre krig mod havets og jordens store riger.

\section{Noter}

1. "[Tasso] soppresse i cavalieri erranti, e cavò l'intreccio non dallo spirito di avventura, ma dall'azione celeste e infernale, come in Omero.«Francesco De Sanctis, Storia della letteratura italiana. Tomo II, Bari 1964, p. 149-150. Hvor intet andet er anført, står forfatteren for de respektive oversættelser. Tak til Anders Toftgaard for kritisk gennemlæsning og konstruktive forslag til oversættelserne fra Liberata.

2. Der findes kun en forkortet genfortælling ved Christine Daugaard: Det befriede Jerusalem, Kbh. 1884, $391 \mathrm{s.}$

3. Passagen er alt andet end overrendt af den kritiske litteratur. Sergio Zatti beskæftiger sig kortfattet med Liberatas Satanskikkelse og undrer sig over, at passagen så sjældent har været diskuteret - jeg har ikke kunnet finde andre nyere kritiske behandlinger (Sergio Zatti: L'uniforme cristiano e il multiforme pagano, Milano 1983, p. 27-29). Jeg har bruger Lanfrenco Carettis autoritative udgave af Tassos epos (Gerusalemme Liberata, Milano 1992). Referencer til Liberata står med henvisning til sang (med romertal) og strofe (med arabertal).

4. "Quinci, avendo pur tutto il pensier vòlto/ A recar ne' cristiani ultima doglia,/ che sia, comanda, il popol suo raccolto/ (concilio orrendo!) entro la regia soglia;/ come sia pur leggiadra impresa, ahi stolto!,/ il repugnare a la divina voglia:/ stolto, ch'al Ciel s'agguaglia, e in oblio pone/ come di Dio la destra irata tuone« (IV, 2).

5. "Siede Pluton nel mezzo, e con la destra/ sostien lo scettro ruvido e pesante;/ né tanto scoglio in mar, né rupe alpestra,/ ch'anzi lui non paresse un picciol colle,/ sì la gran fronte e le gran corna estolle.// Orrida maestà nel fero aspetto/ terrore accresce, e più superbo il rende:/ rosseggian gli occhi, e di veneno infetto/ come infausta cometa il guardo splende,/ gl'involve il mento e su l'irsuto petto/ ispida e folta la gran barba scende,/ e in guisa di voragine profonda/ s'apre la bocca d'atro sangue immonda« (IV, 6-7).

6. „Tartarei numi, di seder più degni/ là sovra il sole, ond'è l'origin vostra,/ che meco già da i più felici regni/ spinse il gran caso in questa orribil chiostra/gli antichi altrui sospetti e i feri sdegni/ noti son troppo, e l'alta impresa nostra;/ or Colui regge a suo voler le stelle,/ e noi siam giudicate alme rubell«(IV, 9).

7. "l'uom vile e di vil fango in terra nato« $(\mathrm{IV}, 10)$.

8. "non sono anco estinti/ gli spirti in voi di quel valor primiero,/ quando di ferro e 
d'alte fiamme cinti/ pugnammo qià contra il celeste impero./ Fummo, io non ,l nego, in quel conflitto vinti/ pur non mancò virtute al gran pensiero./ Diede che che si fosse a lui vittoria/ rimase a noi d'invitto ardir la gloria.«(IV, 15).

9. Satan: »alle menneskelige folks store fjende vendte sine blysorte øjne mod de kristne«»il gran nemico de l'umane genti/ contra i cristiani i lividi occhi torse«, IV, 1). Og Gud: »Han betragtede alle ting, og fæstnede sig derefter ved de kristne prinser i Syrien« ("Mirò tutte le cose, ed in Soria/ s'affisò poi ne" principi cristiani«, I, 8). 10. Se også Sergio Zatti op. cit. p. 28-29.

11. I sin bog The Prince of Darkness (London 1989) gennemgår Jeffrey B. Russell djævleskikkelsens historie og nævner mange eksempler på en talende djævel i den tidligere litteratur. Men enten figureres djævelen som en grovkomisk, parodisk figur - som i middelalderens mysteriespil - eller som frister af den enkelte, troende kristne, modelleret over djævelen der frister Kristus i ørkenen. Den eneste undtagelse er et oldengelsk heltekvad, Genesis, der i sin genfortælling af verdens skabelse også kommer ind på Lucifers oprør. Jeg tror godt, man kan udelukke, at Tasso kendte til Genesis.

12. Dante Alighieri La Divina Commedia, sang VI vers 142 og VII 1-15, XXXIV 1669 (ed. Fredi Chiapelli, Milano 1965). Dantes Lucifer bygger videre på et traditionelt topos i den kristne fremstilling af Satan, nemlig at han indtil den yderste dag skal ligge lænket på bunden af helvede.

13. Klaus Werner gennemgår i sin bog Die Gattung der Epos nach italienischen und französischen Poetiken (Frankfurt a. M. 1977) en række af tidens forsøg på at genoptage den episke genre, og nævner ikke andre, hvor Satan optræder.

14. I starten af første sang henvender Tasso sig til sin mæcen, fyrsten Alfonso II d'Este med håbet om, at han kan blive »Goffredos konkurrent«, og opfordrer ham til at holde våbnene parat $(\mathrm{I}, 5)$. Se også Paul Larivaille: Poesia e ideologia. Letture della Gerusalemme Liberata, Napoli 1987, p. 37-38.

15. Det vil sige lange, fortællende digte skrevet i strofeformen ottave rim. Boiardos Orlando Innamorato (Den forelskede Roland) og Ludovico Ariostos Orlando Furioso (Den rasende Roland) er de mest kendte - men udgør kun toppen af isbjerget. I samtiden kaldtes ridderdigtene nogle gange »Romanzi«, nogle gange "poemi cavallareschi». Jeg oversætter med "ridderdigte«, ikke "ridderroman« eller det noget upræcise »romance», blandt andet for at betone afstanden til middelalderens ridderromaner.

16. Francesco de Sanctis, op. cit. p. 174-175.

17. Franco Fortini, »Tasso epico«, p. 379-80. I Manuale di letteratura italiana, ed. Franchi Bioschi/Costanza Di Girolamo, Bolati Boringhieri 1994. Se også David Quint Epic and Empire, Princeton 1993, p. 213. Begge fokuserer på de dele af receptionshistorien, der har forholdt sig til Liberatas genremæssige placering. Der findes i øvrigt undtagelser, f. eks. Guido Baldassarris Il sonno di Zeus, Roma 1982.

18. G.W.F. Hegel: Vorlesungen über die Esthetik III, Frankfurt a. M. 1970. For Hegels kobling mellem den episke genre og historiske epoker, se p. 339ff. For opgøret med klassikkens episke forsøg se p. 367ff. For bedømmelsen af Tasso se p. 412.

19. Tolkningen finder man ikke kun i den ovenfor citerede L'uniforme cristiano e il multiforme pagano, men også i Zattis nyere bog L'ombra del Tasso (Milano 1996), der utvetydigt læser epos og ridderdigtning som semiotiske koder, hvis indhold henviser til henholdsvis renæssancens dennesidige åbenhed og modreformationens kristne disciplin. Forestillingen genfindes også hos Paul Larivailles (op. cit.) og David Quint (op. cit.). De forskellige tolkninger er i øvrigt kun enige om, at de to 
genrer knytter an til henholdsvis modreformation og renæssance. Når man kommer til, hvordan genrernes symbolske gehalt mere præcist skal defineres, ja, så hersker der endog betydelige uenighed.

20. Se Carlo Dionisotti »La letteratura italiana nell'età del concilio di Trento« for en detaljeret gennemgang af den (manglende) forbindelse mellem litteraturens og modreformationens historie, i Geografie e storia della letteratura italiana, Torino 1967.

21. Jean Marie Schaeffer: Qu'est-ce qu'un genre littéraire, Paris 1989, og »Literary Genres and Textual Genericity« i The Future of Literary Theory, ed. Ralph Cohen, London 1989. Både bog og artikel er perspektivrige - men også meget komprimerede. Den følgende gennemgang udreder ikke baggrunden for alle Schaeffers pointer, men gennemgår det, der er relevant for artiklen.

22. Poetikken var således ikke med i Aldus Manutius første samlede græske udgave af Aristoteles værker fra 1495, men nok i alle trykte udgaver af Aristoteles samlede værker efter 1550. Følger man Carlo Dionisottis gennemgang af oversættelser og optryk af Poetikken, blev bogen oversat til latin i 1498, men vandt først udbredelse efter 1548; Klaus Werner viser dog, at såvel Giangiorgio Trissinos som Bernadino Daniellos poetikker (hhv. 1529 og 1536), som begge omhandler den episke genre, er påvirket af Aristoteles. Se Charles B. Schmitt Aristotele and the Renaissance, Harvard 1983, p. 150-151; Carlos Dionisotti: „La letteratura italiana nell'età del concilio di Trento«, og Werner: Die Gattung der Epos p. $17 \mathrm{ff}$.

23. Hermann Grosser: La sottigliezza del disputare, Firenze 1992, p. 2-3.

24. Werner, op. cit. p. 9-10.

25. Det gjaldt i alt fald de fleste. Enkelte teoretikere - mest kendte er Giambattista Pigna og Giambattista Giraldi Cintio - forsvarede dog også det italienske ridderdigt som genre (Werner op. cit., p. 69ff). Man bør måske nævne, at renæssancens genreteoretikere ikke på nogen måde opfattede Den Guddommelige Komedie som et epos.

26. Discorsi dell'arte poetica var i hovedtrækkene færdig i 1562, men blev revideret løbende de følgende år. Der er konsensus om, at skriftet udtrykker Tassos litteraturteoretiske meninger i perioden, hvor han skrev Liberata. Se også Larivaille op. cit., side 31-32. Jeg citerer teksten efter Torquato Tasso: Discorsi del arte Poetica e del poema eroico, ed. Luigi Poma, Bari 1964.

27. Op. cit., p. 22, $30 \mathrm{ff}$.

28. Jeg oversætter »il meraviglioso«med »det fantastiske«. Det er ikke helt præcist, men i mine øjne bedre end »det eventyrlige« for så vidt som det betoner bruddet med en 'normal' logik - det sandsynlige. De to ord (fantastisk/eventyrlig) opfattes i denne sammenhæng synonymt.

29. »Poco dilettevole è veramente quel poema che non ha seco quelle maraviglie che tanto movono non solo l'animo de gli ignoranti, ma de' giudiciosi ancora«. Op. cit., p. 6 .

30. "Attribuisca il poeta alcune operazioni, che di gran lunga eccedono il poter de gli uomini, a Dio, a gli angioli suoi, a' demoni o a coloro a' quali da Dio o da' demoni è concessa questa podestà, quali sono i santi, i maghi e le fate. Queste opere, se per se stesse saranno considerate, maravigliose parranno, anzi miracoli sono chiamati nel commune uso di parlare. Queste medesime, se si avrà riguardo alla virtù e alla potenza di chi l'ha operate, verisimili saranno giudicate; perché, avendo gli uomini nostri bevuta nelle fasce insieme co , l latte questa opinione, ed essendo poi in loro confermata da i maestri della nostra santa fede [...] e leggendo e sentendo ogni dì 
ricordarne novi essempi, non parrà loro fuori del verosimile quello che credono non solo esser possibile, ma stimano spesse fiate esser avvenuto e poter di novo molte volte avvenire. Si com ${ }^{6}$ anco a quegli antichi, che viveano negli errori della lor vana religione, non deveano parer impossibili que' miracoli che de' lor dei favoleggiavano non solo i poeti, ma l'istorie talora.« Op. cit. p. 7-8.

31. Vergil: Eneiden, I, 37-49; oversat af Otto Steen Due, København 1996.

32. "Qui mille immonde Arpie vedresti e mille/ Centauri e Sfingi e pallide Gorgoni,/ molte e molte latrar voraci Scille,/ e fischiar Idre e sibilar Pitoni,/ e Polifemi orrendi e Gerioni;/ e in novi mostri, e non più intesi o visti,/ diversi aspetti in un confusi e misti.»(IV, 5).

33. Jupiter forbyder Juno at gribe ind i krigen mellem Æneas og Turnus, men tillader til gengæld, at Latium beholder sit navn og sprog - og altså ikke omdøbes af trojanerne (Eneiden XII, 793-842). Den tilsvarende scene i Liberata falder i midten af bogen, hvor ærkeenglen Michael sendes til kampene omkring Jerusalem for at bortjage de djævle, der kæmper på muslimernes side. Og der er ingen forsoning: "Gå bort, forbandede, til jeres rige, smertens og den evige døds rige«. (»Itene, maledetti, al vostro regno,/ regno di pene e di perpetua morte«. IX, 64).

34. Franco Fortini, op. cit. p. 378-379.

35. Inden Tasso udgav Liberata sendte han det til ,intern censur ${ }^{6}$ hos en gruppe af litterære og religiøse autoriteter. Det kom der en lang brevveksling ud af. I denne behandles Satans tale kun en enkelt gang. Se Torquato Tasso Lettere Poetiche, ed. Carla Molinari, Parma 1995, s. 282-283. Se også Werner op. cit., p. 159-160 for kritikken af Liberata.

36. "What though the field be lost?/ All is not lost; the unconquerable Will,/ And study of revenge, immortal hate/ And courage never to submit or yield:/ And what is else not to be overcome?/ That Glory never shall his wrath or might/ Extort from me.« John Milton: Paradise Lost I, 101-109. Jeg citerer fra Norton Critical Edition, London 1975.

37. „Or Colui regge a suo voler le stelle,/ e noi siam giudicate alme rubelle« (IV, 9).

38. Milton, op. cit. I, 248-249.

39. Forbindelserne mellem Miltons Satan i Paradise Lost og romantikernes brug af Satanfiguren er detaljeret kortlagt af Mario Praz i The Romantic Agony (1933), Oxford 1970, p. 58ff. Også Praz starter ved Tasso; for Praz er Tassos Satan-skikkelse imidlertid mere middelalderlig end moderne - og det, fordi han hverken er trist eller udtryk for »a fallen beauty«. Ikke desto mindre gestalter Tasso som den første Satan som den storladne oprører.

40. Se Jeffrey B. Russell: Mephistopheles - The Devil in the Modern World, Ithaca 1986, p. 175.

41. Ezio Raimondi og Hermann Grosser har undersøgt de markante stilistiske fornyelser, Tasso frembringer i sit forsøg på ud fra de klassiske forlæg at udvikle en »høj stil«på italiensk. Guido Baldassarri påpeger, at de homeriske epers detaljerigdom (i senrenæssancen beskrevet som Homers evne til at "particoleggiare») formodentlig har indvirket på Liberatas detaljerede beskrivelser af kampene omkring Jerusalem. Og Michael Murrin mere end antyder i sin History and Warfare in Renaissance Epic (Chicago 1994, p. 206ff.), at Liberatas tvetydige skildring af korsriddernes modstandere kan forklares gennem disse modstanderes forlæg i den klassiske epik. Ezio Raimondi: »Poesia della retorica«i Poesia come Retorica, Firenze 1980; Hermann Grosser op. cit.; Guido Baldassarri, op. cit., p. 49ff.

42. At litteraturens selvstændiggørelse foregår gennem imitationen af litterære klas- 
sikere kan lyde paradoksalt, men er - som Pascale Casanova viser det i sin bog La République mondiale des lettres (Paris 1999) - på det nærmeste et strukturelt træk ved den måde, de litterære felter konstituerer sig. Drager man en parallel til argumentet hos Pascale Casanova, kan man sige, at den litterære antik spillede samme rolle for den italienske senrenæssance som den franske litteratur kom til at spille for udbredelsen af den »autonome«, moderne litteratur i fin-de-siècle-Europa: et universelt og litterært ideal, man både kunne og burde efterligne, idet man samtidig afviste sin egen, regionale tradition.

43. Franco Moretti udvikler i sin bog The Modern Epic (London 1996, p. 55) en tilsyneladende identisk model for principperne i litteraturens evolution. Han skriver således: „This is why literary ideology is always somewhat askew in relation to others: because it rests upon a jumble of fortuitous experiments, rhetorical fetters and unpredictable turns. «- "Unforeseen 'ideology ... and unforeseen for a very simple reason: because they are born not as ideologies but as rhetorical experiments«. Men samtidig fastholder Moretti et syn på den episke genre, der er hentet direkte fra Hegel, og gør brug historiefilosofiske skemaer, der kun anerkender to epoker i verdenshistorien (den førmoderne og den moderne), hvorfor hans forestillinger om forholdet mellem litteratur og historie alligevel befinder sig et godt stykke fra denne artikels. 